\title{
Smallholder Farmers' Access to Agricultural Insurance Schemes: An Analysis of the Inhibitors in Kogi State, Nigeria
}

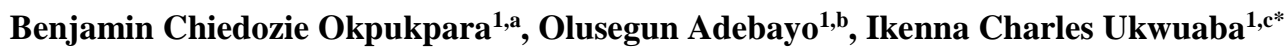 \\ ${ }^{1}$ Department of Agricultural Economics, University of Nigeria, Nsukka, Nigeria \\ *Corresponding author
}

A R T I C E I N F O A B S T R A T

\section{Research Article}

Received : 16/04/2021

Accepted : 07/12/2021

Keywords:

Agricultural insurance

Constraints

Small-scale farmers

Kogi State

Nigeria
The study examined the constraints of access to the use of agricultural insurance schemes (AIS) by small-scale farmers in Kogi State, Nigeria. Sustainable agricultural enterprise in most developing countries like Nigeria can be achieved through adequate financing especially in the area of agricultural insurance. Despite the existence of insurance services by the Nigerian Agricultural Insurance Corporation and other private firms in Nigeria, there has been a low level of participation of farmers buying insurance premium; thus, there is a need to examine the hindrances in accessing the scheme. The specific objectives were to describe the socio-economics characteristic of smallscale farmers, examine the types of agricultural insurance and evaluate the constraints in accessing AIS in the study area. Primary data were collected from 150 farmers with the aid of a well-structured questionnaire. Data were analyzed using descriptive statistics. Results showed that farmers in the study area were dominated by the married (68\%), literates $(81.33)$ and males $(73.33 \%)$ with the mean age and farming experience of 47 and 19 years respectively. Crop insurance (56\%) and farm implement insurance $(46 \%)$ were the major types of agricultural insurance used by the farmers. Rigorous procedures in claim settlement (3.266), poor government attention (3.106) poor repayment (3.080) and non-coverage of all the crops (3.093) were among the major challenges in accessing AIS) in the study area. The study recommended that the government through the ministry of Agriculture or Bank of Agriculture should eliminate the bureaucratic processes and bottlenecks encountered by the farmers in accessing AIS. benjamin.okpukpara@unn.edu.ng c@ikenna.ukwuaba@unn.edu.ng
(iD) https://orcid.org/0000-0001-6751-1313
(iD) https://orcid.org/0000-0002-3534-9785

b@segunnihale@gmail.com

(D) https://orcid.org/0000-0002-0555-4753

\section{Introduction}

Smallholder farmers constitute a large proportion of the agricultural sector and contribute significantly to food security and the gross domestic product of Sub Saharan Africa. Particularly; in Nigeria, agriculture is dominated by small-scale farmers who produce over 90 per cent of the total agricultural output in the country (FAO, 2018). The Agricultural sector in Nigeria has contributed greatly to foreign exchange earnings and poverty reduction (Chikaire et al., 2015). However, World Bank (2018) stated that small- scale farmers in many developing countries of the world including Nigeria are trapped in the vicious cycle of poverty. This cycle is characterized by low productivity and low farm income which leave them with virtually no saved up capital required for the transformation of their production technology, and consequently, to the low status accorded to farmers in the society (Falola et al., 2013). The farmers are further constrained by the inherent risks and uncertainties associated with agriculture.
The risks and uncertainties encountered by farmers arise principally due to the nature of agriculture. Production risks, marketing risk, financial risks, personnel or legal risks are the major forms of risks faced in Sub Saharan Africa. Production or biological risk is one of the principal risks faced by small-scale farmers. The overall effect of these risks has been devastating and disastrous as most farmers are often on the verge of losing their means of livelihood or been thrown out of their farm enterprise (Pelka et al., 2015); and therefore, a major contributing factor to the slow rate of growth of Nigeria's food production and food insecurity in Nigeria. Many smallholder farmers in Kogi State, Nigeria are confronted with these risks, and thus, it has become increasingly necessary that these farmers take formal insurance to mitigate the risks and uncertainties that come with farming. This is attributed to the fact that the traditional risk minimization strategies are unfavorable and somewhat 
ineffective and thus, cannot adequately absorb the resultant economic shocks of agricultural risks on the farmers (Nnadi et al., 2013).

Insurance is one of the ways of managing and mitigating risk. Conventionally, insurance is defined as the equitable transfer of risk of loss from one entity to another in exchange for a premium or a guaranteed and quantifiable small loss to prevent a large and possibly devastating loss (Schaffnit-Chatterjee, 2010). Epetimehin (2012) opined that agricultural insurance is designed to provide covers for financial losses incurred due to unexpected reduction in output from agricultural products. The primary motive of any agricultural insurance policy is to serve as a security for losses resulting from natural disasters and also serves as collateral for an agricultural loan to the farmers (Pelka et al., 2015). However, smallholder farmers lack of access to agricultural insurance remains one of the banes of agricultural growth in Kogi State, Nigeria.

The Nigerian Agricultural Insurance Scheme (NAIS) was birthed in recognition of the need for a special support programme for agricultural development that addresses the fundamental problems of risks and uncertainties. The scheme was aimed at reducing the impact of risks and uncertainties to an acceptable minimum (Mafimisebi, 2007). Yusuf (2010) in his study stated that, though NAIS had significantly benefited farmers, there exist challenges that had adversely affected the realization of the goals of the scheme. Some of the challenges include low penetration and participation of commercial banks in agricultural finance in the scheme as well as difficulty in designing new agricultural insurance products among others. Mahul and Stutley (2010) also opined that government-sponsored agricultural insurance programs and participation by the farmers have been disappointing. The implication of such a state of the agricultural insurance scheme in Nigeria will spell great doom for both the farmers and on the food security status of the nation.

Successive government has introduced various incentives programmes to ensure that agricultural insurance is patronized, sustained and beneficial to the insurer; this effort, however, has not made much impact (Akinola, 2014). Similarly, Sinha (2012) affirmed that the majority of rural farmers are precluded from accessing agricultural insurance services and as a consequence, they are pushed to cope with using traditional risk minimization strategies which were not so effective and reliable. Furthermore, Mahul and Stutley (2010) also noted that from the perspective of most subsistence farmers, agricultural insurance is regarded as luxury; affordable to only a few farmers; thus, farmers seek effective and efficient government intervention to make agricultural insurance more affordable and accessible. Eric and Mathenge (2015) also asserted that even though awareness of agricultural insurance is a key precursor for its use, only a few farmers understand how it works and thus, this prohibits their ability to decide as regards its usage. Besides, the unaffordability of premiums and inaccessibility of insurance services especially as a result of distribution challenges have also hindered its adoption (Eric et al., 2015).

Though the Nigerian Agricultural Insurance Corporation and other private firms have been rendering insurance services in Nigeria, there has been a low level of participation of farmers buying insurance premium and in view of this, there is the need to examine limiting factors to the use of agricultural insurance in the study area. Furthermore, although Kogi State is predominantly an agrarian state, researches on agricultural insurance and its accessibility by farmers are limited in the literature. Previous studies, by Adah et al. (2016), was on the assessment of rural farmers' attitudes toward agricultural insurance scheme as a risk management strategy in Kogi State while Ibitoye (2012) focused on the assessment of the levels of awareness and use of Agricultural Insurance Scheme among the rural farmer. However, little or no work has specifically addressed the constraints faced by smallscale farmers in Kogi state in accessing and using the agricultural insurance scheme. This study, therefore, is to fill the gap in the literature. The specific objectives of the study were to describe the socio-economic characteristics of small-scale farmers, examine the types of agricultural insurance available and investigate the factors that constrain farmers' access to the agricultural insurance scheme. This is very necessary to bring about confidence in investment in agriculture and also makes it easier for lending institutions to extend agricultural loans to small scale farmers and consequently reduce the poverty level.

\section{Materials and Methods}

\section{Study Area}

The study area was Kogi State. Lokoja, the capital of the state is situated at the confluence of rivers Niger and Benue. Kogi state is located between latitude $7^{\circ} 49^{\prime} \mathrm{N}$ and longitudes $6^{\circ} 45^{\prime} \mathrm{E}$. It has 21 local Government Areas (LGAs) with a population of about 2.1 million people (NPC, 2006), and four agricultural zones designated as A, B, C and D. The State has two distinct seasons; the dry season runs between November and February and raining season which starts from March and ends in October. The average annual rainfall is between 850 and 2000 millimeters. The relative humidity is moderately high and varies from an average of $65 \%$ to $85 \%$ throughout the year (Amhakhian et al., 2012). The vegetation of the state is made up of rainforest in the south and woody derived savannah and Guinea savannah in the north. The landmass is generally flat or gently undulating, and it lies between 50 and 700 meters above sea level.

Kogi state has a geological feature depicting young sedimentary rocks and alluvium along the river beds which promote agricultural activities. The rich soil types and conducive agricultural climate are being effectively utilized by over $70 \%$ of the population that is engaged in agricultural activities (Adah et al., 2016). The farmers produce crops such as yam, cocoyam, cassava, maize, soya bean, sorghum, rice, cowpea, beni-seed, among others. River Niger and Benue along with other rivers and streams provide the area with abundant fishing opportunities. However, the Rivers Niger and Benue predispose the farmlands to occasional flooding, especially during the rainy season. The flooding is usually severe and often destroy crop farms, leading to the loss of livelihood on the part of the farmers. The Nigerian Agricultural Insurance Scheme office is located in Lokoja, the state capital which is meant to facilitate the access of the AIS by the farmers in the study area. 


\section{Sampling Procedure and Data Collection}

A multi-stage sampling technique was employed in the selection of the respondents. In stage one; two LGAs were randomly selected from each of the four agricultural zones. Stage two involved a random selection of five villages from each of the eight LGAs selected, culminating in 40 villages. In the third stage, a random selection of four small - scale farmers from each of the 40 villages. The choice of equal number of respondents selected from the sampled areas was based on the need to ensure equal representation of respondents from each LGA as the study area is an agrarian area. In all, 160 respondents were selected for the study. Data for the study were collected from primary source with the aid of a semi-structured questionnaire designed to capture information on the specific objectives. Trained enumerators helped in the collection of the data. However, only 150 questionnaires were retrieved and used for the analysis.

\section{Data Analysis}

Descriptive statistics such as mean, frequencies, percentages, and Likert-type scale were used to realize the objectives. A 4-point rating scale technique was employed to ascertain information regarding the factors that constrained farmer's access to AIS in Kogi State. It was designated as extremely severe, very severe, severe and not severe with the corresponding values of $4,3,2$, and 1 respectively. This was ranked using a weighted mean $(x)$. The mean score (MS) of the respondents based on the four 4-point scale was gotten thus:

$$
\frac{\boldsymbol{\Sigma} \boldsymbol{f} \boldsymbol{x}}{\mathbf{n}}=\frac{4+3+2+1}{4}=2.50
$$

A 2.50 cut off point using the interval scale of 0.05 was adopted; the upper limit cut off point was $2.50+0.05=$ 2.55 while the lower limit cut off point was $2.50-0.05=$ 2.45. Therefore, any inhibitor to agricultural insurance access with a mean score less than 2.45 (i.e. MS < 2.45) was considered as a weak factor and thus less severe while mean values above 2.55 (i.e. MS > 2.55) were regarded significant and thus rated as major inhibitors in accessing agricultural insurance scheme in the study area.

\section{Results and Discussion}

\section{Socio-economic Characteristics of the Respondents}

The result in Table 1 showed that $73.33 \%$ of respondents were males while $26.67 \%$ of the respondents were females. The result implied that the males dominated the farming activities in the area. This is not surprising considering the stressful and demanding nature of farming in most developing countries where mechanized farming is not common; most farmers have to clear, plough, cultivate and harvest farm produce manually using hoes and cutlasses. Only a few women can engage in such demanding and energy-sapping activities. The result corroborated the findings of (Agbo and Usoroh, 2015; Awotide et al., 2014) who reported the dominance of male farmers in Akwa Ibom State and Oyo state Nigeria respectively. The marital status of the respondents indicated that the majority of the farmers $(68 \%)$ were married, while few $(8 \%)$ were single. This implied that more married people were engaged in farming in the study area. This could be attributed to the fact that farming is labour intensive and requires both direct and indirect labour contributions from the family members to reduce the cost of paid labour. The majority $(58.01 \%)$ of the respondents were within the age range of 41 to 60 years. The mean age of the farmers was 47 years, implying that typical farmers in the area were in the economically active age group. This is primarily because farming in the study area is rarely mechanized and therefore, requires farmers with vigour, strength, and physical fitness; thus, younger farmers possessed the required energy and agility to actively participate in crop farming and other related activities. More so, younger farmers are relatively more dynamics and willing to take risks associated with farming activities; and purchasing agricultural insurance. The finding is in tandem with the work of Olarinde et al. (2005) that found that old people tend to be risk-averse than young people. This result aligned with the findings of Ogunmefun and Achike (2015) who reported a modal age range of 30 to 50 years among farmers in Ogun, state, Nigeria.

Concerning the educational status of the respondents, the results showed that the majority (81.33\%) of the farmers had formal education while only $18.67 \%$ had no formal education. The result indicated that the farmers in the study area had a significant and appreciable level of education which would not only help them in the better management of the farm and accurate record keepings but also in the better understanding of all the technical jargons; and terms and conditions in accessing agricultural insurance schemes. The educational level of the respondents is also a huge advantage that could translate to efficient management of the resources and improved farm income level. The result corroborates the findings of Ukwuaba et al. (2020) who reported a high educational status among crop farmers in Enugu Ezike Agricultural Zone of Enugu State, Nigeria. The majority (63.33\%) of the respondents engaged in crop production while few $(9.33 \%)$ were involved in livestock production in the study area. About $27 \%$ of the respondents combined both crop production and animal farming in the study area. This could be attributed to the fact that crop production is comparatively less risky, cheaper and easier to manage compared to livestock production. Also, the combination of both crop and animal farming also serve as a form of diversification and serve as a shock absorber and make up for either crop failure or animal mortality.

The result of the farming experience showed that the majority (46\%) of the respondents had between one to 15 years of farming experience whereas $41 \%$ of the farmers had 16 to 30 years of farming experience. Only about $13 \%$ of the respondents (13.3\%) had farming experiences above 30 years while the mean years of farming experience were 19 years. Therefore, the result suggested that most of the respondents have been in the business of farming for years and that farming is their main means of livelihood in the area. The result also suggests that the farmers are well-grounded, well experienced and knowledgeable in the farming enterprise. The longer a farmer spends in the farm business, the more efficient the farmer becomes in the day to day management of the farm enterprise. The mean farm size of the respondents was 3.03 hectares, implying that most of the farmers were smallholders and subsistence farmers. The small farm size is directly connected to the system of land ownership or land tenure system in the study area which limits the use of machinery and as a consequence, makes mechanization unattractive, unprofitable and uneconomical. 
Table 1. Socio-economic characteristics of the respondents

\begin{tabular}{|c|c|c|c|}
\hline Socio-economic characteristics & Frequency & Percentage & Mean \\
\hline Gender & & & \\
\hline Female & 40 & 26.67 & \\
\hline Male & 110 & 73.33 & \\
\hline Marital Status & & & \\
\hline Single & 12 & 8.00 & \\
\hline Married & 102 & 68.00 & \\
\hline Divorced & 20 & 13.33 & \\
\hline Widowed & 16 & 10.67 & \\
\hline Age & & & 46.62 \\
\hline $20-40$ & 51 & 34 & \\
\hline $41-60$ & 85 & 58.01 & \\
\hline $61-75$ & 12 & 8.02 & \\
\hline Educational Status & & & 8.5 \\
\hline No formal education & 28 & 18.67 & \\
\hline Primary education & 35 & 23.33 & \\
\hline Secondary education & 55 & 36.67 & \\
\hline Tertiary education & 32 & 21.33 & \\
\hline Farm Type & & & \\
\hline Crop farming & 95 & 63.33 & \\
\hline Livestock farming & 14 & 9.33 & \\
\hline Livestock and crop & 41 & 27.33 & \\
\hline Farming experience & & & 19.14 \\
\hline $1-15$ & 69 & 46 & \\
\hline $16-30$ & 61 & 40.67 & \\
\hline $31-40$ & 20 & 13.34 & \\
\hline Farm size $(\mathrm{Ha})$ & & & 3.03 \\
\hline $0.5-2.0$ & 61 & 67.34 & \\
\hline $2.1-3.5$ & 44 & 29.34 & \\
\hline $3.6-5.0$ & 32 & 21.34 & \\
\hline $5.1-8.5$ & 43 & 8.66 & \\
\hline Household size & & & 5.43 \\
\hline $1-5$ & 76 & 50.67 & \\
\hline $6-10$ & 73 & 48.66 & \\
\hline 11 & 1 & 0.67 & \\
\hline Monthly income (Naira) & & & $67,572.22$ \\
\hline $0-50,000$ & 11 & 7.32 & \\
\hline $50,001-100000$ & 35 & 23.33 & \\
\hline $100,001-200,000$ & 104 & 69.34 & \\
\hline Total & 150 & 100 & \\
\hline
\end{tabular}

Source: Field Survey, 2018

Table 2. Types of agricultural insurance used in the study area

\begin{tabular}{l|cc}
\hline \multicolumn{1}{c|}{ Type of Insurance } & Frequency & Percentage \\
\hline Crop insurance & 85 & 56.67 \\
Livestock insurance & 51 & 34.00 \\
Farm implement & 69 & 46.00 \\
Multiple peril crop insurance & 53 & 35.33 \\
Revenue insurance & 29 & 19.33 \\
\hline Total & 150 & 100.00 \\
\hline
\end{tabular}

Source: Field Survey, 2018, *Multiple Responses

Table 3. Constraints to the agricultural insurance scheme

\begin{tabular}{l|lcccc}
\hline S/N & \multicolumn{1}{c}{ Constraints } & Mean & Std. Dev & Decision & Rank \\
\hline 1 & Rigorous procedures in claim settlement & 3.2667 & 0.9244 & Accepted & $1^{\text {st }}$ \\
2 & Poor govt. attention to the scheme & 3.1067 & 0.9840 & Accepted & $2^{\text {nd }}$ \\
3 & Inadequate financial resources & 3.0933 & 1.0449 & Accepted & $3^{\text {rd }}$ \\
4 & Non-coverage of the scheme to every crop & 3.0800 & 1.0651 & Accepted & $4^{\text {th }}$ \\
5 & Lack of access to the insurance scheme & 3.0267 & 1.0423 & Accepted & $5^{\text {th }}$ \\
6 & No access to credit & 2.8667 & 1.0011 & Accepted & $6^{\text {th }}$ \\
7 & Distance to the scheme & 2.8200 & 1.0748 & Accepted & $7^{\text {th }}$ \\
8 & Inadequate information dissemination & 2.3051 & 1.4275 & Rejected & $8^{\text {th }}$ \\
\hline
\end{tabular}


About $50 \%$ of the respondents had a household size between one to five while few $(0.67 \%)$ had household size above 11 members. The mean household size of the respondents was five persons. The result implied that the respondents had an available labour force to assist in the farming business. This is very important considering that most of the farming activities in the study area were manually done and thus, large household size will contribute significantly as family labour and help reduce the money that would have gone into paid labours. Therefore, the more the household size, the greater the labour force available for farm works. However, Osondu and Ijeoma (2014) reported that large household size could limit the net returns from the farming business due to the diversion of potential investment funds to increase household consumption expenses. The mean monthly income of the respondents was $\$ 67,572.22$, (117.35USD). The result showed that an average farmer in the study area earns an amount that is at least twice the federal government approved national minimum wage of $\$ 30,000$ (78.74 USD). The mean monthly farm income could triple if an agricultural insurance scheme is made more accessible to farmers, as it could reduce the risk and losses farmers encounter in their farming businesses.

\section{Agricultural Insurance Types Used by the Respondents}

The types of agricultural insurance used by the respondents in mitigating agricultural risks are presented in Table 2. The result showed that about $57 \%$ of the farmers used crop insurance, while $46 \%, 35 \%$ and $34 \%$ of the respondents employed farm implement insurance, multiple peril crop insurance and livestock insurance schemes respectively in mitigating and managing agricultural risks and uncertainties. This implied that large proportions of the farmers are using formal insurance methods in combating agricultural production and marketing risks in the study area. The result is consistent with the findings of Yusuf (2010) and Tsikiayi et al. (2014) in Kebbi State, Nigeria and Zimbabwe respectively that reported that crop insurance, livestock insurance and Multiple peril crop insurances as the major types of agricultural insurance used in the study areas.

\section{Inhibitors to Farmers' Access to Agricultural Insurance Scheme}

The constraints militating against access to agricultural insurance scheme in the study area were shown in Table 3. The result showed that farmers' access to agricultural insurance scheme was plagued by many critical problems. These problems greatly reduced farmers capacity to access and use the agricultural insurance scheme to lessen the impact of risks and uncertainties in their farming enterprises and consequently, some of the farmers were left with no option but to use the traditional means of risk mitigation which were not so effective. The findings showed that rigorous procedures in claim settlement (3.266) topped the list as the most significant constraints faced by the smallholder farmers in accessing agricultural insurance scheme in the study area. The long bureaucratic processes and the corresponding low level of claim settlement reduces the impacts of agricultural insurance on the smallholder farmers' livelihood and farm business.
Thus, it is expected that low bureaucratic procedures would motivate and stimulate the majority of the respondents in accessing and utilizing the insurance scheme as a safety net and a potent means of mitigating risks on their farm enterprise. The result is in line with the findings of OlajideAdedamola and Abiodun (2018) who reported that protracted processes and procedures in accessing agricultural insurance in Western, Nigeria.

Poor government attention to the scheme (3.106) and inadequate financial resources (3.093) ranked second and third respectively as the major constraints in accessing and using agricultural insurance in the study area. The result is not unconnected to the poor government attention, corruption and lip services to the development of Agriculture in Nigeria. This is evident in the poor budgetary allocation to agriculture in Sub Saharan Africa over the years. In Nigeria, the average budgetary allocation to agriculture in the past six years is $1.4 \%$, this is far below the $10 \%$ Maputo Declaration Benchmark. Agriculture is a risky business, and being a smallholder is even riskier. Government insincerity and poor attention have become major setbacks to agricultural growth. Therefore, Government should pay adequate attention to agricultural financing through access to credit as well as agricultural insurance to enable the resource-poor farmers to use the insurance as a coping strategy amidst a risky business environment.

Other hindrances to the use of agricultural insurance scheme as a risk mitigation option include non-coverage of the scheme on every crop (3.080), lack of access to the insurance scheme (3.026), no access to credit (2.866), and distance to the scheme (2.820). Again, due to poor funding of agriculture in Nigeria and Kogi state in particular, the agricultural insurance provided by the Nigeria Agricultural Insurance Scheme is selective in nature; that is, it did not cover all crops. This ugly situation meant that some farmers who grew non-insurable crops are exposed to risk which could lead to the loss of their farm business. Also, due to the selectivity of the available agricultural insurance in the state, some farmers are not covered or protected by any insurance. Therefore, these crops of farmers lacked complete access to agricultural insurance and thus are forced to use ineffective traditional risk mitigation strategies.

The farmers in the study area also lacked access to credit and as such could not get a loan to support their farming or to even access the available agricultural insurance. Access to credit facility would spur the farmers to subscribe to government insurance or even the almost unaffordable insurance provided by the private sectors. Due to the nature of agribusiness and the inherent risks therein, most commercial banks find it difficult to disburse credits to smallholder farmers. Finally, a well spread NAIS offices within the 21 LGAs or at least in the four agricultural zones in the state will increase access to AIS. However, the long-distance of the scheme's office to most of the farmer is very discouraging. The NAIS have only one office in Lokoja, the state capital. This implied that aside from the few farmers that reside around the Lokoja axis, the rest will have to travel a long distance before they could access the insurance office. Even when one eventually makes it to the office; the long bureaucratic processes and unnecessary delays become the order of the day. This ugly situation discourages most farmers, 
especially the old, fragile and resource-poor farmers. This result implied that these variables have in different ways hampered farmer's ability to access agricultural insurance scheme in Kogi state, Nigeria.

The result is consistent with the findings of Ibitoye (2010) who reported that the major problems preventing the usage of agricultural insurance by the farmers in the Kwara state were fear of failure to honour the agreement, high insurance premium, inadequate financial resources and non-coverage of many crops. The result also confirmed the reports of Tsikirayi et al., (2014) in Zimbabwe; Ogunmefun and Achike (2015) in the Odogbolu local government area of Ogun State, Nigeria. Tsikirayi et al., (2014) reported that limited knowledge on insurance, lowincome levels, low agricultural production, remoteness of farms from service providers and negative perceptions about insurance, in general, were the major constraints to farmers accessing agricultural insurance in Zimbabwe while Ogunmefun and Achike, similarly reported that lack of credit, lack of credit facilities, lack of working capital (assets like land) and lack of skills (education), and also high costs of inputs were the major problems farmers encountered in accessing and using agricultural insurance programme in Ogun state, Nigeria

Conversely, inadequate information dissemination (2.305) was reported as a minor and insignificant constraint in accessing agricultural insurance scheme in the study area. This result could be attributed to the effectiveness of agricultural extension agents in the area, who disseminate innovation and/or technology, including agricultural insurance from research institutes or information from the government to the end-users which are mainly farmers. The high level of awareness could also be credited to the availability of mass media such as radios and televisions in the study area. Other sources of awareness or information dissemination are through farmers' cooperatives, Newspapers, friends and relatives.

\section{Conclusion and Recommendations}

Agricultural insurance remains one of the surest ways of mitigating risks and uncertainties inherent in agriculture. The study examined the inhibitors in accessing agricultural insurance scheme by small scale farmers in Kogi state, Nigeria using primary data collected from 150 small-scale farmers selected through a multi -staged sampling techniques. Majority of the farmers were literate married men, who are experienced in farming and in their active age. Crop insurance, livestock insurance and farm implement insurance were the major types of agricultural insurance used by the farmers. However, the bureaucratic bottlenecks in accessing agricultural insurance scheme, non-coverage of all of the crops as well as the poor government attention to the scheme in Kogi state were identified as the major setbacks to AIS accessibility. Therefore, we recommend that concerted efforts by the government at all levels and other relevant stakeholders through the ministry of Agriculture or Bank of Agriculture are needed to reduce the bureaucratic processes and bottlenecks encountered by the farmers in accessing AIS. In addition, the Government of Kogi state should establish AIS in all parts of the state to increase the proximity between farmers and the AIS office.

\section{References}

Adah OC, Chia JI, Shaibu MU. 2016. Assessment of rural farmers' attitudes toward agricultural insurance scheme as a risk management strategy in Kogi State, Northcentral Nigeria. Journal of Economics and Sustainable Development 7, (14), $12-19$.

Agbo FU, Usoroh BA. 2015. Marketing of estruine shrimps in Awka Ibom State, Nigeria. Journal of Marketing and Consumer Research, 15 (7), 63-70.

Aina OS, Omonona BT. 2012. Nigerian Agricultural Insurance Scheme (NAIS): Prospect, achievement and problems. Global Advanced Resources Journal of Agricultural Science, 1(5), 97-103.

Akinola DB. 2014. Determinants of farmers' adoption of agricultural insurance: the case of poultry farmers in Abeokuta metropolis of Ogun State, Nigeria. British Journal of Poultry Sciences 3(2): 36-41.

Amhakhian SO, Oyewole CI, Osemwota I. 2012. Response of maize (Zea mays 1) yield and yield components to rates of applied phosphorus (Capsicum annum L). An M.Sc Thesis, submitted to the University Agricultural Science; Dharwad. India.

Awotide BA, Abdoulaye T, Alene A, Manyong VM. 2014. Assessing the extent and determinants of adoption of improved cassava varieties in south-western Nigeria. Journal of development and agricultural economics, 6(9), 376-385.

Chikaire JU, Tijjani AR, Abdullahi KA. 2015. The perception of rural farmers of agricultural insurance as a way of mitigation against climate change variability in Imo State, Nigeria.International Journal of Agricultural Policy and Research, 4 (2), 17-21.

Epetimehin FM. 2012. Agricultural insurance in Nigeria and economic impact. InternationalJournal of Agricultural Economics, Management and Development. 1(1): 56 - 71.

Eric N, Kirimi L, Mathenge M. 2015. Uptake of Crop Insurance in the face of Climate Change: Evidence from Smallholders in Kenya.A paper prepared for presentation at the 16th Global Development Network Conference, 11th-13th June 2015, Casablanca-Morocco.

Falola A, Ayinde OE, Agboola BO. 2013. Willingness to take agricultural insurance by cocoa farmers in Nigeria. International Journal of Food and Agricultural Economics, 1(1), 97-107.

Food and Agricultural Organization (2018). Smallholders data portrait. Available at: www.fao.org/family-farming/datasources/dataportrait/farm-size/en

Ibitoye SJ. 2010. Influence of farm size, educational status and farm income on the adoption of maize varieties in Kogi State, Nigeria. American-Eurasian Journal of Sustainable Agriculture. 4(1), 20-25.

Ibitoye SJ. 2012. Assessment of the levels of awareness and use of agricultural insurance scheme among the rural farmers in Kogi State, Nigeria. International Journal of Agricultural Science, Research and Technology,2(3), 143-148.

Mafimisebi TE. 2007. Like Garbage in Garbage Out: The Effects of Sector-Targeted Public Insurance Programme on Nigeria's Agriculture.

Mahul O, Stutley CJ. 2010. Government support to agricultural insurance: Challenges and options for developing countries. Washington D.C., World Bank Publications.

National Population Commission 2006. 2006 Population and Housing Census of the Federal Republic of Nigeria, Abuja. Vol. 1 pp: 67-76.

Nwani AT, Omankhanlen AE. 2019. Insurance receivables and economic growth: the case of Nigeria. Journal of Physics: Conference Series 1378 (2019) 042093: 1-15. 10.1088/17426596/1378/4/042093

Ogunmefun SO, Achike AI. 2014. Socioeconomic characteristics of rural farmers and problems associated with the use of informal insurance measures in Odogbolu local government area, Ogun State, Nigeria. Research Journal of Agricultural Science, 2(38),3 -14. 
Olarinde LO, Ajao AO, Okunola SO. 2015. Determinants of Technical Efficiency in Bee-Keeping Farms in Oyo State, Nigeria: A Stochastic Production Frontier Approach. Research Journal of Agriculture and Biological Sciences, 4(1), 65-69.

Osondu CK, Ijioma JC. 2014. Analysis of profitability and production determinants of fish farming in the capital territory of Abia State, Nigeria. World Journal of Agricultural Sciences, 2 (7): 168-176.

Pelka N, Musshoff O, Weber R. 2015. Does weather matter? How rainfall affects credit risk in agricultural microfinance. Agricultural Finance Review, 75 (2),194-212

Schaffnit-Chatterjee C. 2010. Risk Management in Agriculture: Towards Market Solutions in the EU. Germany: Deutsche Bank Research Frankfurt am Main.
Sinha 2012. Agriculture Insurance in India, Centre for Insurance and Risk Management Working Paper Series.

Tsikirayi CMR, Makoni E, Matiza J. 2014. Analysis of the uptake of agricultural insurance services by the agricultural sector in Zimbabwe. Journal of International Business and Cultural Studies, 22(5), 36-45.

Ukwuaba IC, Owutuamor BZ, Ogbu CC. 2020. Assessment of agricultural credit sources and accessibility in Nigeria. Review of Agricultural and Applied Economics 23 (2),3 -11. Yusuf KK. 2010. Insurance Options in Risk Management in Agriculture Finance. A paper presented on the occasion of the AFRICA Conference in Abuja 